\title{
TDP-43 Proteinopatileri: \\ Nörodejeneratif Konformasyon Bozukluğu Hastalıklarında Yeni Bir Oyuncu
}

\author{
TDP-43 Proteinopathies:
}

A New Player in Neurodegenerative Diseases with Defective Protein Folding

\author{
Suna Lahut*, Burçak Özeş*, Soykan Ağar, A. Nazlı Başak \\ Boğaziçi Üniversitesi, Moleküler Biyoloji ve Genetik Bölümü, İstanbul, Türkiye \\ *IIlk iki yazar yazıya eşit katkıda bulunmuştur.
}

Özet

Hücredeki proteinlerin toplamına proteom, proteomun hücre içindeki stabil durumuna proteostaz denilir. Proteostazın korunması için, proteinlerin doğru konsantrasyonu, hatasız ekspresyonu, düzgün üç-boyutlu katlanması, translokasyonu ve gerekli durumlarda yıkımı sağlanmalıdır. Genetik ve çevresel faktörler sonucu proteinlerin yanlış katlanma ve agregasyona-yatkın bir konformasyona dönüşmesi, hücre stresini artırır. Birçok kanıt, hasarlı protein birikiminin, sadece hücre-içi süreçlerin verimliliği ve hassasiyetine doğrudan olumsuz etki yapmakla kalmadığını, düzeltilmedikleri takdirde, işlev bozukluğu şelalesini tetikleyerek, proteinopatiler olarak adlandırılan bir dizi protein konformasyonu bozukluğu hastalığına neden olduğunu göstermektedir. Günümüzde özellikle yaşlı popülasyon oranları yüksek, gelişmiş toplumları tehdit eden, Alzheimer Hastalığı (AD), Parkinson Hastalığ (PD), Huntington Hastalığ 1 (HD), Amiyotrofik Lateral Skleroz (ALS), kanser, diyabet vb. hastalıklar genelde protein katlanma bozukluğundan kaynaklanırlar. Bu yazıda, gerek güncelliği, gerekse birçok farklı hastalıkta etkin olması nedeniyle TDP-43 proteini, neden olduğu proteinopatilerin en iyi araştırılmış örnekleri olan ALS ve FTLD üzerinden incelenmiştir. (Türk Nöroloji Dergisi 2012; 18:1-10)

Anahtar Kelimeler: TDP-43, nörodejenerasyon, protein katlanmas1, agregasyon, ALS, FTLD, model sistemler

\section{Summary}

The proteome is the sum of all proteins inside a cell, and proteostasis (protein homeostasis) is the stable condition of the proteome. Proteostasis is essential for the cellular and organismal health. Stress, aging and the chronic expression of misfolded proteins challenge the proteostasis machinery and the vitality of the cell. There is increasing evidence that the accumulation of damaged proteins not only has direct consequences on the efficiency and fidelity of cellular processes but also, when not corrected, that they initiate a cascade of dysfunction, which in humans is associated with a plethora of diseases of protein conformation, referred to as proteinopathies. Alzheimer's Disease (AD), Parkinson's Disease (PD), Huntington's Disease (HD), Amyotrophic Lateral Sclerosis (ALS), cancer and diabetes, whose frequencies have drastically increased in countries with aging populations, are all consequences of misfolded proteins. This paper focuses on TDP-43, which excelled as a key protein in neurodegenerative processes because of its association with different diseases, especially with ALS and Frontotemporal Lobar Dementia (FTLD), the two best studied examples of TDP-43 proteinopathies (Turkish Journal of Neurology 2012; 18:1-10)

Key Words: TDP-43, neurodegeneration, protein folding, aggregation, ALS, FTLD, model systems

\section{Giriş}

\section{Proteom, Proteostaz ve Protein Katlanmasi}

Bir hücrenin tüm proteinlerinin toplamına proteom denir. Proteomun işlevini hatasız bir şekilde yerine getirmesi, hücresel süreçler için en temel şartlardan biridir ve canlı organizmaların oluşumları ve yaşamlarını sağlıklı bir şekilde sürdürmeleri için büyük önem taşır. Tüm hücrelerde, proteomun hatasız bir şekilde işlemesinden, şaperon, transport molekülleri, ubikitin-temelli proteozom ve otofajik sistem gibi karmaşık yapıları barındıran moleküler bir ağ sorumludur (1-7).

Yazışma Adresi/ Address for Correspondence: Dr. Nazlı Başak, Boğaziçi Üniversitesi, Moleküler Biyoloji ve Genetik Bölümü, İstanbul, Türkiye Tel.: +90 2123597298 E-mail: basak@boun.edu.tr

Geliș Tarihi/Received: 27.01.2012 Kabul Tarihi/Accepted: 31.01 .2012 
Yeni bir terminoloji olan protein homeostazı ya da proteostaz, hücre içindeki proteinlerin (proteomun) birbirleri ile olan tüm moleküler ilişkilerinin düzenlenmesidir. Proteostaz için, proteinlerin doğru konsantrasyonu, hatasız ekspresyonu, düzgün üç-boyutlu katlanması, translokasyonu ve gerekli durumlarda yıkımı sağlanmalıdır. Hücre stresi ve yaşlanması, proteostazı ve sözü geçen karmaşık ağ yapısının dengesini olumsuz yönde etkiler ve belirli bir eşik değeri aşıldıktan sonra da özellikle nöron düzeyinde, hücre patolojisi ve hastalık riski ciddi şekilde $\operatorname{artar}(8-10)$ (Resim 1).

Proteinler, natif ya da doğal yapı diye adlandırılan yüksek çözünürlüklü işlevsel yapılarını kendilerine özgü, üç-boyutlu, fizyolojik katlanmalarıyla kazanırlar. Proteinin (polipeptid zincirinin) doğal yapısına katlanması birincil yapısındaki aminoasitlerin dizisine, moleküler şaperonların ve görevli protein ve enzimlerin işlevine bağlıdır. Her proteinin sınırlı bir katlanma kapasitesi vardır, hücresel kalite kontrol mekanizmalarından kurtulan yanlış katlanmış protein zincirleri kendi aralarında intermoleküler hidrojen bağları oluşturarak agrege olmaya çok yatkındırlar $(1-3,5,12,13)$.

Proteinlerin fizyolojik yapısını kazanması gibi, proteinin yanlış katlanması da tüm canlı organizmaların yaşamlarının doğal bir parçasıdır. Ökaryotlarda sentezi tanımlanan tüm proteinlerin üçte birinin şaperon yardımına rağmen fizyolojik konformasyonlarını kazanamadıkları tahmin edilmektedir.
Bunun yanında yanlış protein katlanması genetik mutasyonlar ve bir dizi post-translasyonel modifikasyon (oksidasyon, glikasyon, nitrosilasyon gibi) sonucu da olabilir (3).

Proteinin doğru katlanması, sadece proteinin kendisi için değil, hücre ve tüm organizma için yaşamsal önem taşır. Protein katlanması için gerekli olan bilgi, temelde proteinlerin birincil yapisında, yani amino asit dizilerinde kodlanmakla birlikte, hücresel ortamın etkisi de son derece önemlidir; benzer proteinler farklı ortamlarda farklı şekillerde katlanabilirler. Hücre ortamı proteinin doğal yapısının stabilitesini kontrol ederek işlevselliğini korur. Bu yoğun hücresel ortamın yanısıra, bireye özgün çeşitlilikler, polimorfizmler, ve zaman içinde yaşlanma ile biriken bir dizi protein translasyonu sonrası modifikasyon da protein katlanmasını olumsuz yönde etkiler. Tüm bu faktörler, stabil olan natif protein yapısının yanlış katlanma ve agregasyonayatkın metastabil bir konformasyona dönüşmesine neden olur ve hücre stresini artırır $(14,15)$ (Resim2).

Protein katlanma süreci hem kooperatif, hem de kompleks olduğu için, konformasyonel geçişleri ve kısa-ömürlü ara molekülleri karakterize etmek son derece güçtür. Agregasyonun öncüleri ne birincil yapıdaki ne de fizyolojik olan üçüncül yapıdaki proteinlerdir. Amiloid oluşumundan, hiç katlanmamış birincil yapıdaki protein zinciri ile natif yapıya çok yakın olan üç-boyutlu yapı arasındaki, aracı

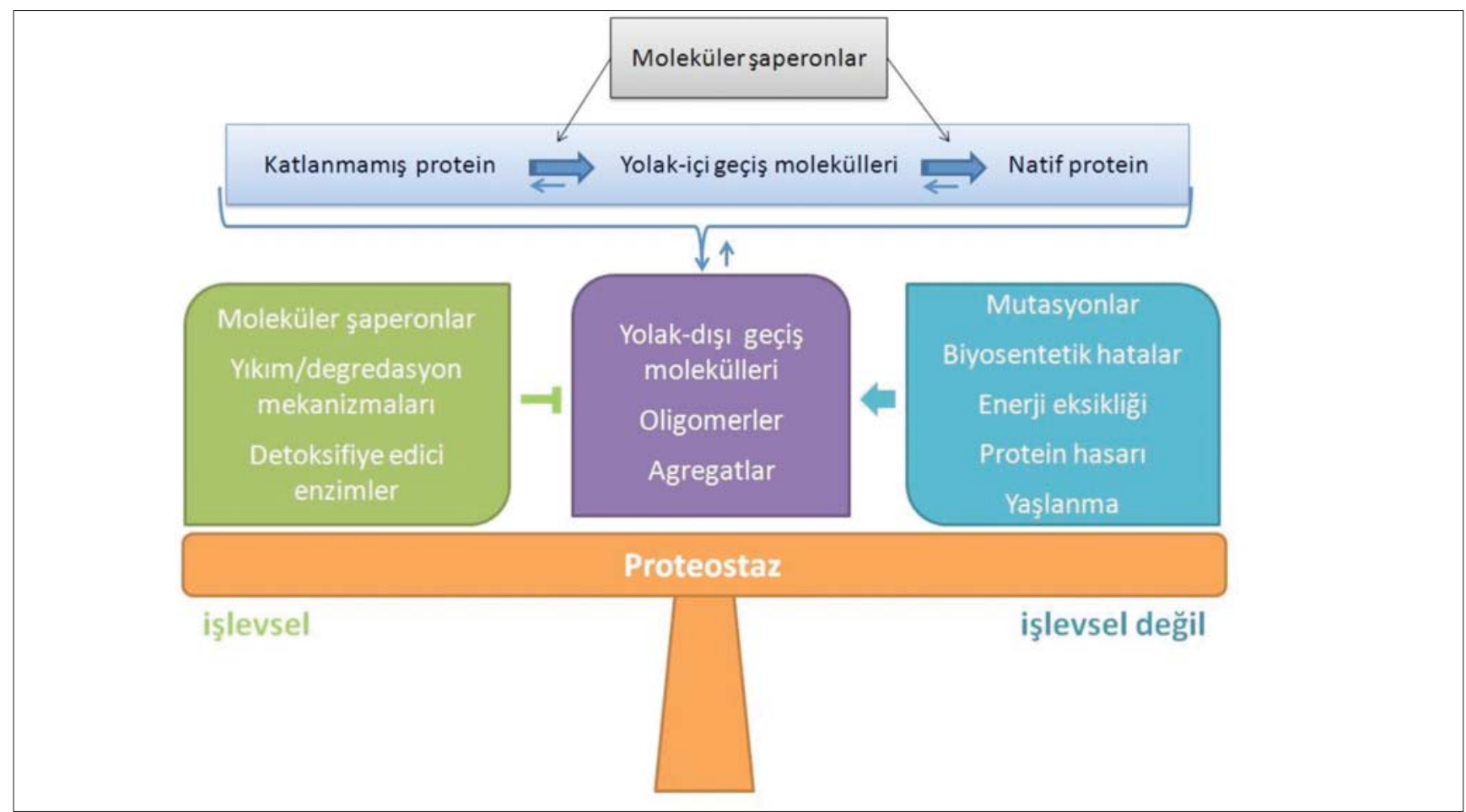

Resim 1. Proteostaz, hücre içindeki tüm proteinlerin fizyolojik düzeylerinin, doğru katlanmalarının, ikincil ilişkilerinin ve hücrenin farklı kısımlarındaki lokalizasyonlarının sağlanabilmesi, korunabilmesi ve doğru dengede tutulabilmesidir. Özellikle nöron seviyesinde birçok kompleks mekanizmayı içeren bu dengenin să̆lanmasının,

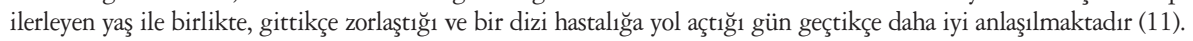


moleküller sorumludur, bunlar belirgin ikincil yapıları dolayısıyla agregasyona yatkındırlar (genellikle alfa heliksden ziyade beta-plak). Amiloid fibrillerinin yapısı son derece stabil, degradasyona dayanıklı ve çözünürlükten uzaktır; bu yapılar düşük enerjileri dolayısıyla normal fizyolojik katlanma ile yarış halindedirler (Resim 3). Protein agregasyonunun en önemli nedenlerinden biri protein konformasyonunu değiştiren mutasyonlardır $(4,16)$.

Proteom yapısının dinamik özelliğine karşın proteostaz çok kontrollüdür; hem hücrenin en ideal şartları oluşturabilmesi için özerk olarak (cell autonomous), hem de hücreler- ve dokular-arası özerkliği să̆lamak açısından, hücreden bağımsız olarak (non-cell autonomous) düzenlenir; bu işlevlerin hatasız işlemesi, hücrenin sağlı̆̆ını ve organizmanın yaşam süresini belirler $(18,19)$.

Protein konformasyon değişikliğinin neden olduğu stres, proteostaz ve hücre için önceden tahmin edilemeyen, son derece olumsuz bir etkendir ve hücrenin buna hazırlıklı olması gereklidir (Resim 4). Yaşlanma sürecinde ortaya çıkan, örneğin mutant ve zarar görmüş proteinlerin ekpresyonu sonucu oluşan 1 ș şoku, oksidanlar, metabolik ve kronik stres gittikçe biriken hücre hasarına neden olurlar $(20,21)$.

Mutant proteinlerin birikimi, sadece hücresel süreçlerin etkinliğini ve düzenli çalışmasını olumsuz olarak etkilemekle

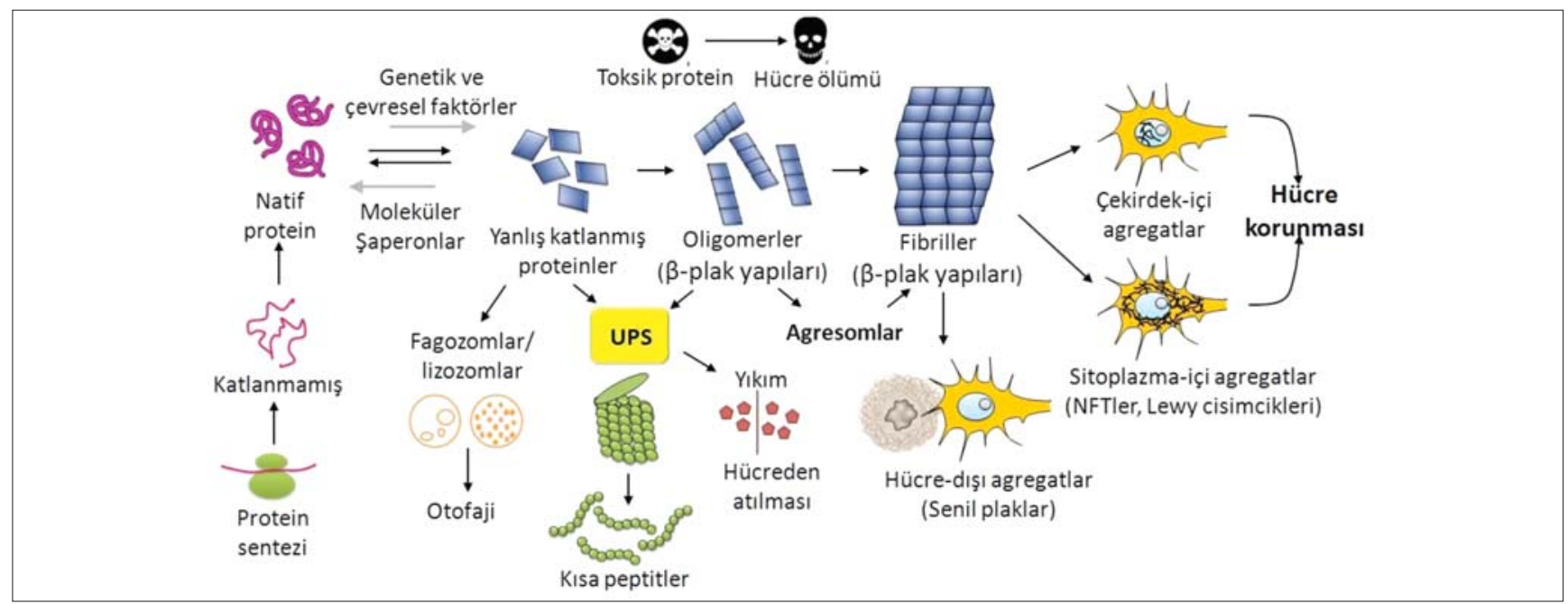

Resim 2. Protein katlanması ve yanlış katlanmış proteinlerin oluşturduğu stres durumları UPS: Ubikütin Proteozom sistemi, NFT: Nörofibriler yumaklar (15).

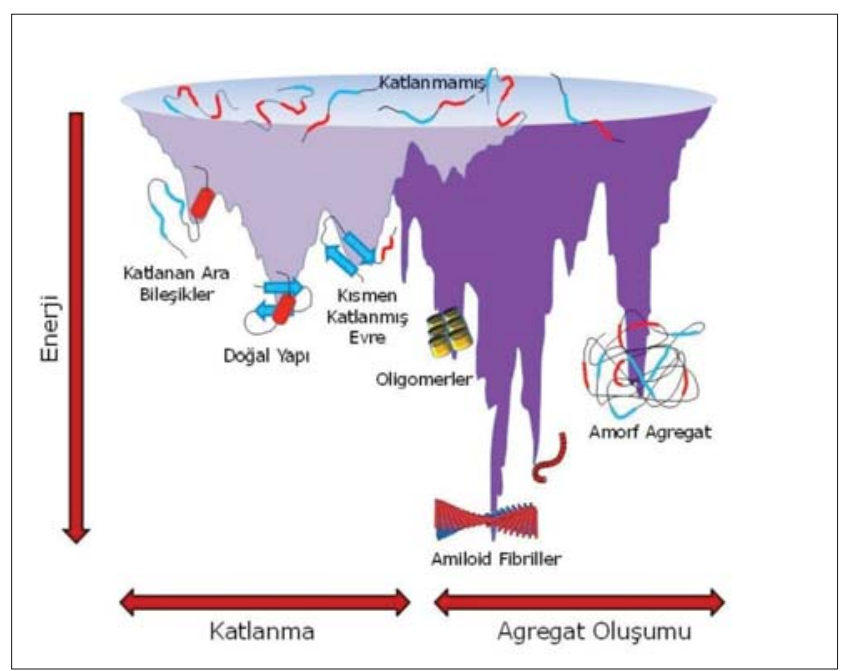

Resim 3. Protein katlanmasının ve agregasyonunun enerji haritasi: eflatun kısım intramoleküler ilişkilerle desteklenen natif konformasyonları, mor kısım ise intermoleküler bağlantılardan oluşan agregasyon ve amiloid fibrilleri destekleyen konformasyonları göstermektedir. Her iki enerji düzeyi örtüşmektedir; agregasyonlar hem yeni zincirlerin oluşumundan, hem de natif konformasyonun destabilizasyonundan kaynaklanabilir ve normalde moleküler şaperonlar tarafından engellenir (17).

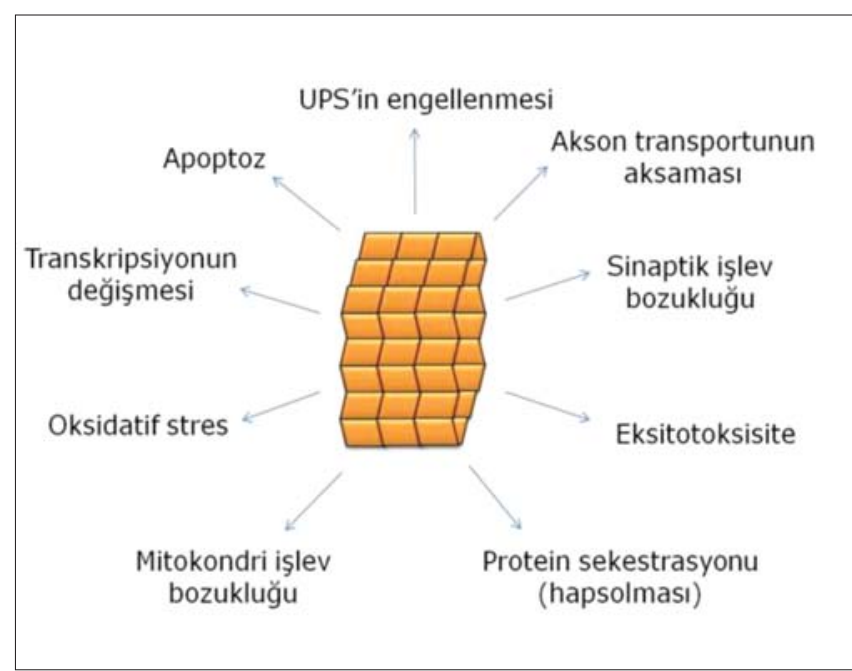

Resim 4. Protein konformasyon değişikliğinin neden olduğu toksik mekanizmalar (22). 
kalmaz, hücre tarafından tamir edilmedikleri sürece birbirini zincirleme takip eden bir dizi işlev bozukluğuna neden olurlar. Bunların sonucunda, günümüzde özellikle yaşlı popülasyon oranları yüksek olan gelişmiş toplumları ciddi bir şekilde tehdit eden, AD (23,24), PD (26), HD (27), ALS (28), kanser (29), diyabet (30) vb. protein katlanma bozukluğu hastalıkları (foldopathies) ortaya çıar. Her ne kadar bu hastalıklar kendilerine özgü hücre ve dokuları etkileyerek özgün klinik fenotiplere yol açsalar da, hepsinin ortak noktası agregasyona yatkın proteinlerin varlığıdır (Resim 5). Bu yazının konusu, gerek güncelliği, gerekse birçok farklı hastalıkta etkin olması nedeniyle TDP-43 proteini ve son yıllarda, özellikle nörodejenerasyon araştırmalarının odak noktası olan TDP-43 proteinopatileri ile en iyi incelenmiş örnekleri olan ALS ve FTLD'dir (31).

\section{TDP-43 Geni, Proteini ve Agregasyonu}

TDP-43 [TAR (Transactive Response) DNA-BindingProtein-43] ilk olarak HIV1 virüsünün TAR DNA-dizisine bağlanarak transkripsiyonunu baskılama özelliğine sahip bir protein olarak tanımlandı. Daha sonra, kistik fibrozis'de alternatif kırpılma işlemini düzenleyen bir faktör olduğu görüldü. Tüm dokularda yüksek miktarda sentezlenen 414 aminoasit uzunluğundaki TDP-43 proteini, omurgasılardan memelilere kadar bütün canlılarda evrimsel olarak çok iyi korunmuştur. Sağlıklı hücredeki lokalizasyonu çekirdekte olan TDP-43, DNA/RNA bağlayıc1, heterojen ribonükleer protein (hnRNP) A/B ailesine ait bir proteindir ve bir dizi farklı görevi vardir (3,32-34).
TDP-43'ün işlevsel bölgeleri, nükleer lokalizasyon ve nükleer eksport sinyalleri, nükleik asitlere bağlandı̆̆ 1 iki RNA tanı1c1 motifi, ve glisin amino asitince zengin ve protein-protein ilişkilerinden sorumlu karboksil (C-) terminalidir (Resim 6). C-terminal bölgesi hem diğer hnRNP proteinleri ile olan ilişkiler için, hem de alternatif kırpılmanın ve transkripsiyonel baskılamanın kontrolü için gereklidir. mRNA'ya ve DNA'ya bağlanabilen TDP-43, RNA metabolizmasının farklı aşamalarını (mRNA kırpılması, stabilitesi, translasyonu ve gen transkripsiyonunu) çekirdek ile sitoplazma arasında mekik dokuyarak (NLS ve NES sayesinde) düzenler. C-terminal bölgesi TDP-43 agregasyonu için kritiktir; normal şartlarda çekirdekte bulunan protein, patolojik durumda inklüzyonlar halinde sitoplazmada ve distrofik nöronların uzantılarında (nöritlerde) agrege olur, buna karşılık TDP-43 inklüzyonları hücre çekirdeğinde oldukça nadirdir. TDP-43'ün hücre çekirdeğinden eksilmesi, sitoplazma ve nöritlerdeki inklüzyonların neden olduğu toksik işlev kazanma mekanizmasına ek olarak, bir işlev kaybı türü mekanizmanın varlığına da işaret etmektedir $(3,13,20)$.

TDP-43'de tanımlanmış olan, biri hariç tüm mutasyonların C-terminalinde bulunması, bu bölgedeki yap1 ve işlev değişikliğinin -henüz bilinmeyen bir mekanizmaylanörodejenerasyonu tetiklediğini düşündürmektedir. Hastalık durumunda sadece karboksil terminalini içeren, farklı uzunluklarda fragmentlere parçalanan ve fosforile olan TDP43 proteini bu haliyle agregasyona çok yatkındır. Tipik fibriler oluşumlar göstermeyen ve kongofilik boyalarla

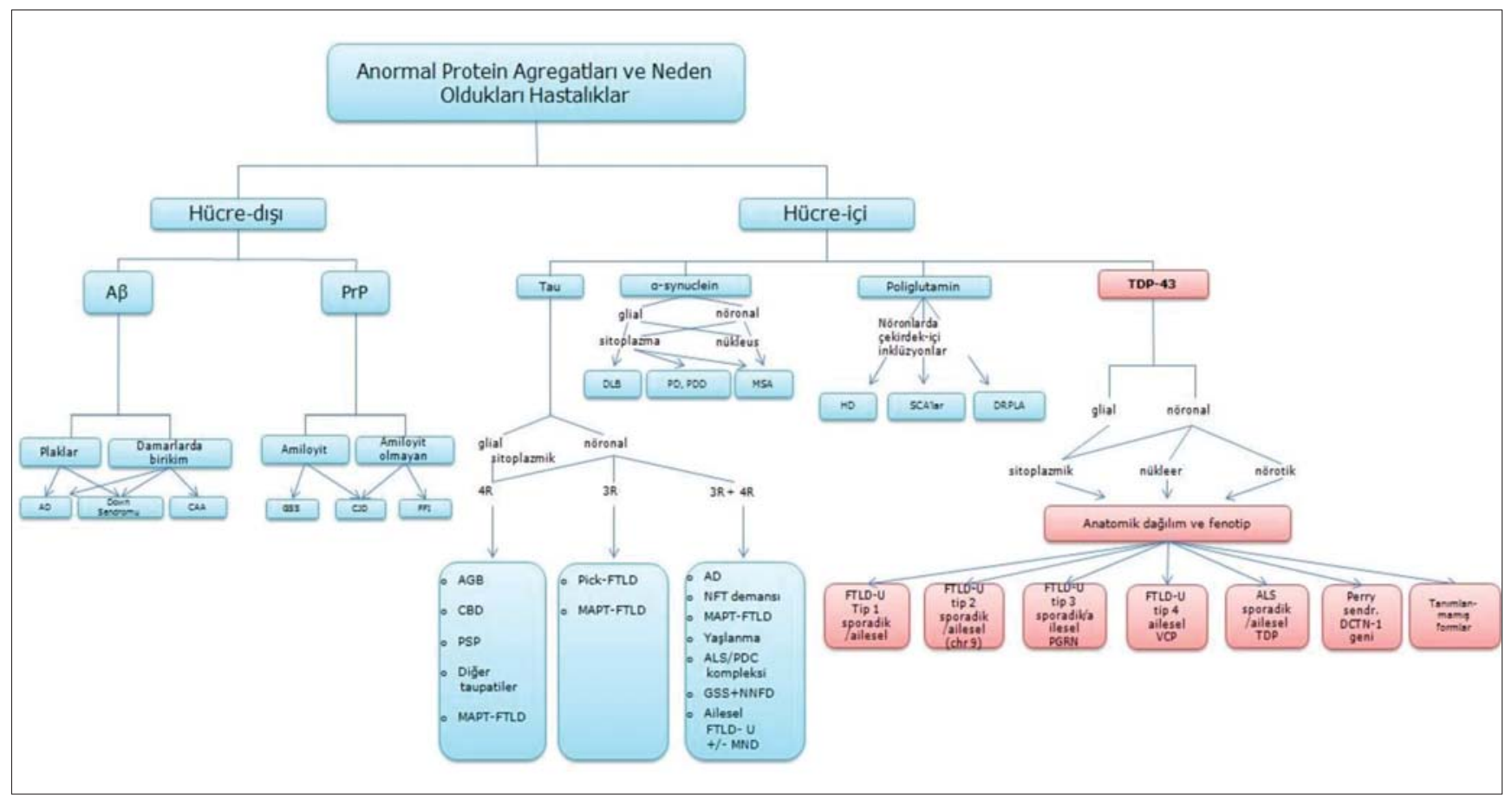

Resim 5. Anormal Protein agregatları, hücre-dışı ve hücre-içi olmak üzere iki büyük gruba ayrılırlar (15). 
boyanmayan TDP-43 agregatlarının yapıları, bilinen amiloid özelliklerini taşımaz, dolayısıyla özgün TDP-43 patolojisi adı altında anilirlar $(13,35)$.

TDP-43 ve Nörodejenerasyon

TDP-43 ilk olarak sadece ALS ve birkaç FTLD olgusuyla ilişkilendirilmiş olmakla birlikte (FTLD-TDP), çok kısa zamanda TDP-43 patolojisinin AD, PD, Difüz Lewy Cisimcikli Hastalık gibi bir dizi nörodejeneratif hastalıkta da etkin olduğu anlaşılmış, hatta son zamanlarda benzer patolojinin 65 yaş üzerindeki sağlıklı popülasyonun yaklaşık \%30'unda da mevcut olduğu görülmüştür (36). Tüm bu olgularda, TDP-43 içeren

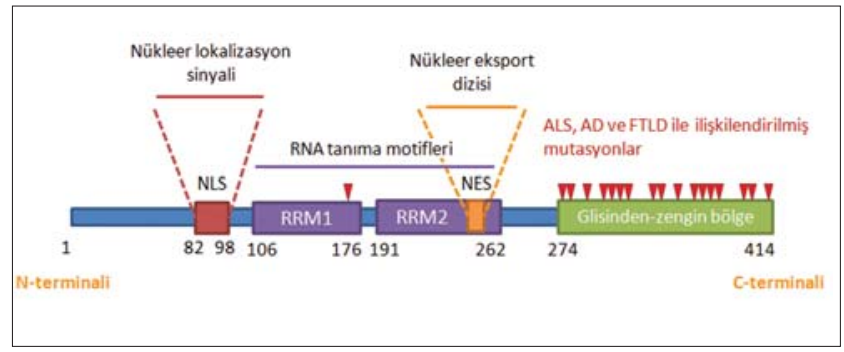

Resim 6. $43 \mathrm{kDa}$ büyüklü̆̆̈undeki TDP-43 proteinini kodlayan 1 . kromozomdaki TARDBP geni. TDP-43’ün, bir nükleer lokalizasyon sinyali (NLS), iki RNA tanıma motifi, bir nükleer eksport dizisi (NES) ve C-terminal bölgesi vardır. Nörodejenerasyona neden olan mutasyonların büyük çoğunluğunu içeren C-terminal bölgesi, hem TDP-43’ün diğer proteinlerle olan ilişkilerinden sorumludur, hem de alternatif kırpılma ve transkripsiyonel baskılama için gereklidir, dolayısıyla bu bölgedeki mutasyonlar protein işlevini olumsuz etkiler $(3,13)$. nöronal ve gliyal sitoplazmik inklüzyonlar, distrofik nöritler ve çok nadir durumlarda intra-nükleer inklüzyon içeren tipik histolojik özellikler mevcuttur, diğer taraftan TDP-43 patolojisinin dağılımı hepsinde farklıdır. ALS ve FTLD-TDP olgularında, neokorteks de dahil, beynin çok geniş bölgeleri etkilenirken, TDP-43 agregasyonu diğer nörodejeneratif hastalıklarda ve sağlıklı yaşlı bireylerde genellikle limbik sisteme kısıtlıdır. Bu bulgular TDP-43 patolojisinin varlı̆̆1 ya da yokluğunun her zaman bir hastalık göstergesi olmadı̆̆ını, buna karşılık anormal TDP-43 dağılımının farklı hastalıklara özgün olabileceğine işaret etmektedir. Anormal TDP-43 boyanmas1, fizyolojik yapıları bozuk olan proteinlerin sitoplazmada agregasyonlar oluşturduğu iki kas hastalığında, inklüzyon cisimcikli miyopatiler ve miyofibriler miyopatiler'de de görülmektedir. Miyofibriler miyopatiler, sitoplazmadaki miyofibriler sistem proteinlerinin mutasyon sonucu üç boyutlu yapılarını kaybederek çökmeleri ile ortaya çıkan hastalıklardır $(37,38)$. Bu olgularda TDP-43 patolojisinin gözlenmesi, sitosoldeki anormal protein agregatlarının yarattığı strese, TDP43 'ün çekirdekten sitoplazmaya geçip agregat oluşumuyla verdiği tepki olarak açıklanabilir. Hücre-içi TDP-43 patolojisi pek çok nörodejeneratif hastalıkta gözlenmesine, yani tek bir hastalığa özgü olmamasına rağmen, TDP-43 mutasyonları yalnızca ALS ve nadiren de FTLD'ye neden olur, diğer hastalıklarda bugüne kadar tanımlanmamıştır. Bu sonuç, TDP-

Tablo 1. Nörodejeneratif hastalıklarda TDP-43 patolojisinin hücre-içi yerleşimi, fizyolojik dağılımı ve görülme sıklığı (13)

\begin{tabular}{|c|c|c|c|}
\hline $\begin{array}{l}\text { Nörodejeneratif } \\
\text { hastalık }\end{array}$ & Hücre-içi & Fizyolojik yerleşimi & $\begin{array}{l}\text { Görülme } \\
\text { siklı̆̆1 (96) }\end{array}$ \\
\hline Amiyotrofik lateral skleroz & $\begin{array}{l}\text { NCI ve GCI» Nll, } \\
\text { DN, nükleustayok }\end{array}$ & $\begin{array}{l}\text { Yaygın: spinal motor nöronlar, frontal ve } \\
\text { temporalneokorteks, basal ganglia, limbik yapılar }\end{array}$ & $\sim 100^{c}$ \\
\hline Frontotemporal demans- TDP & $\begin{array}{l}\text { NCI ve GCI» Nll, } \\
\text { DN, nükleusta yok }{ }^{b}\end{array}$ & $\begin{array}{l}\text { Yaygin: frontal ve temporal neokorteks, basal ganglia, } \\
\text { limbik yapilar }\end{array}$ & $100 \mathrm{e}$ \\
\hline Alzheimer & $\begin{array}{l}\mathrm{NCI} \text { ve GCI» Nll, } \\
\text { DN, nükleusta yok }\end{array}$ & $\begin{array}{l}\text { Çoğunlukla limbik: amigdala, entorhinal, } \\
\text { hipokampüs, dentat, aingulat,insula }\end{array}$ & $33-57$ \\
\hline Parkinson & $\begin{array}{l}\text { NCI ve GCI, } \\
\text { DN, nükleusta yok }\end{array}$ & Çoğunlukla limbik & 19 \\
\hline Lewy cisimcikl i demans & $\begin{array}{l}\text { NCI ve GCI» Nll, } \\
\text { DN, nükleusta yok }\end{array}$ & Çoğunlukla limbik & 45 \\
\hline Kortikobazal dejenerasyon & $\begin{array}{l}\mathrm{NCI} \text { ve GCI» Nll, } \\
\text { DN, nükleusta yok }\end{array}$ & Değişken: çoğunlukla limbik, bazen yaygın & $0-33$ \\
\hline Progresif supranüklear palsi & $\begin{array}{l}\mathrm{NCI} \text { ve GCI» NIl, } \\
\text { DN, nükleusta yok }\end{array}$ & Çoğunlukla limbik & $0-26$ \\
\hline $\begin{array}{l}\text { Demans-Parkinsonizm,- } \\
\text { ALSGuam kompleksi }\end{array}$ & $\begin{array}{l}\text { NCI ve GCI» Nll, } \\
\text { DN, nükleusta yok }\end{array}$ & $\begin{array}{l}\text { Yaygın: frontal ve temporal neokorteks, } \\
\text { bazal ganglia, limbik yapılar, spinal motor nöronlar }\end{array}$ & 100 \\
\hline Huntington & NCI, DN & Aşağ1 neokortikal katmanlar, bazalganglia & 100 \\
\hline
\end{tabular}

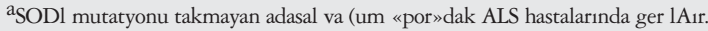

$\mathrm{b}$ farkl FTO-TOP formlarında farkl (distinct) $\mathrm{aK}-\mathrm{t} \ll>1 \ll \mathrm{r}$ goruleMr.

${ }^{\mathrm{c}}$ UtxkiCn nkluzyonları $\mathrm{i}_{\mathrm{i}}$ er an tum FTD tçılerı dahi adikjtgmde, T0P-43 patoVojm \%80-04 çerukr.

NCI. rMronal ntoplarmk ınfcbzyonlar; GCI, 9la! srtopl aırrrk nkluzyonlar ; Nil, nsronal ı*ern.klecr mkJuzyonlar; ON, distrofik ojitler. 
43 işlev kaybı ile ALS/FTLD arasındaki özgün ilişkiyi desteklemekle birlikte, bu bağlantının mekanizması henüz tam olarak açıklanamamıştır (39).

İnsanda TDP-43 patolojisi çalışmaları üç farklı sonuç halinde özetlenebilir: (i) TDP-43 proteininin normalde lokalize olduğu çekirdekten çıkarak sitoplazmada agregat oluşturması, bugüne kadar bilinen TDP-43 hastalıklarında ortak ve tutarlı bir patolojidir, (ii) TDP-43 patolojisinin hücre-içi dağılımı farklı nörodejeneratif hastalıklarda değişkenlik göstermektedir, (iii) TDP-43 patolojisi ALS veya FTLD'ye özgü değildir; pek çok nörodejeneratif hastalıkta ve 65 yaş üstü sağlıklı bireylerde sıklıkla görülmektedir. Hücreiçi TDP-43 agregasyonunun, tüm nörolojik hastalıklarda görülmesi, bu patolojinin ALS/FTLD dışı olgularda da önemli olduğunu ve hatta bu hastalıklarda da TDP-43 agregasyonu ya da işlevini hedef alan tedavi yöntemlerinin faydalı olabileceğini düşündürmektedir $(10,13,36,40)$ (Tablo 1).

\section{TDP-43 ve ALS/FTLD İlişkisi}

ALS hastalarinda sıklıkla frontal lob bozukluğu /dejenerasyonu görülmesi, ALS ve FTLD'nin benzer, hatta ortak bir patofizyolojiye sahip olduklarını uzun zamandan beri düşündürmekteydi (41), 1990'lı yıllardan başlayarak, otopsi yapılan ALS hastalarının motor nöronlarında sıklıkla ubpozitif inklüzyonlara rastlanmakla birlikte, bu inklüzyonların yapıları ve içerdikleri protein türlerine 15 yıl boyunca fazla değer biçilmedi. Ancak 2006 yılında ALS ve FTLD'de görülen çözünülürlügü düşük, ve ub-pozitif, alfa-sinüklein ve taunegatif inklüzyonların ana maddesinin TDP-43 olduğu anlaşıldı (40). ALS ve FTLD olgularında TDP-43 pozitif agregatlar, hem sporadik hastaların çoğunluğunda, hem de TDP-43, VCP (Valosin containing protein) ve progranulintemelli ailesel ALS vakalarında görülmekteydi (42).

Patolojik TDP-43, hiperfosforile ve ubikitin ile işaretli idi, yıkıma uğradığında proteinin sadece C-terminal fragmentlerini içeriyordu ve merkezi sinir sisteminin hastalıktan etkilenen, hipokampüs, neokorteks ve omurilik bölgelerinde görülüyordu. Kisa zamanda TDP-43'deki dominant geçişli nokta mutasyonlarının ALS'ye ve nadiren de FTLD'ye neden oldukları ve değişen TDP-43 işlevinin nörodejenerasyonu doğrudan tetiklediği gösterildi (43-48). $\mathrm{Bu}$, o güne kadar SOD1'in mutlak hakimiyetindeki ALS araştırmalarını $(18,49-51)$ altüst eden önemli bulgu, protein agregasyonunu, diğer bir dizi nörodejeneratif hastalıkta olduğu gibi, ALS araştırmalarının en önemli konularından biri haline getirdi. TDP-43 ve bir yil sonra tanımlanan FUS (52,53), SOD1'in antioksidan enzimatik aktivitesinden çok farklı olarak, RNA biyolojisinde etkin olan çekirdek proteinleridir ve etki mekanizmalarının anlaşılması yolunda bir dizi soruyu gündeme getirirler: ALS RNA-temelli bir hastalık mıdır? İnklüzyonların önemi nedir? Bu inklüzyonlar primer nörotoksisite nedeni mi, yoksa sadece yan ürün, yoksa da hücrenin anormal duruma koruyucu yanıtı mıdır? TDP-43 proteinopatileri yaşamsal işlevlerin kaybı ile mi, yeni bir toksik işlev kazancı türü bir mekanizma ile mi etki etmektedir? Son 5 yıldaki çok hızlı gelişmelere rağmen bu sorular henüz tam olarak yanıtlanamamıştır, yoğun araştırmalar devam etmektedir $(54,55)$.

Sitoplazmik TDP-43 Agregatları: İnklüzyon Yapıları mı, RNA Granülleri mi?

Sitoplazmadaki TDP-43 agregatları ile ilgili ilk çalışmalarda, bu agregatların hücre tarafından gerektiği şekilde yıkılamayan inklüzyonları temsil ettiği düşünüldüyse de, RNA bağlayıcı proteinler ile çalışan araştırmacılar, çekirdekten sitoplazmaya taşınmanın ve sitoplazmadaki RNA granülleri (stress granules/'processing bodies') ile birleşmenin, bu proteinlerin ortak özellikleri olduğunu gözlemledi. Birçok hücre hattında, TDP-43'ün oksidatif stres, proteozom inhibisyonu, 1sı şoku veya ozmotik strese bağlı oluşan sitoplazmik stres granülleri ile birleştiği gösterildi. Stres granülleri, yukarıda belirtilen hücresel stres durumlarında translasyonel baskılanmada görev alan çok sayıda mRNA ve RNA bağlayıcı proteinleri içeren, dinamik sitoplazmik yapılardır. TDP-43'ün varlığı da, yokluğu da stres granülü oluşumunu etkilemez, dolayısıyla bu yapıların oluşumu TDP43’ün temel işlevlerinden biri değildir. Bunlara karşın, sitoplazmik TDP-43 agregatlarının aslında işlevsel ribonükleoprotein kompleksleri olduğu düşünülmektedir. Bu durum, TDP-43 agregatlarının proteotoksik stres altında, neden birçok nörodejeneratif hastalıkta görüldüğünü açıklayabilir. Stres altında, TDP-43'ün sitoplazmik RNA granülleri ile birleşmesi normal bir eğilim olabilir. Bu bulguları takiben yapılan araştırmalarda benzer sonuçlar elde edilemediğinden, bu durumu netleştirecek çalışmalar yapilmaktadır (56-62).

Nörondaki sitoplazmik RNA granüllerinin kendilerine özgü özellikleri olduğu da dikkate alınmalıdır (63). Diğer hücrelerin aksine, nöronlarda TDP-43, stres granüllerinde değil, P-cisimciklerinde (processing bodies) lokalizedir. İçerdikleri proteinler ve RNAlar açısından stres granülleri ile kısmen örtüşen P-cisimciklerinin, RNA yıkımında görev aldıkları düşünülmektedir (64). Dolayısıyla, TDP-43'ün hangi sitoplazmik RNA granülüne bağlanacağı hücre tipine ve ortama göre değişir.

\section{TDP-43 ve Model Sistemler}

Bugüne kadar yapılan modeller sadece mutant TDP-43'ün değil, yabanıl proteinin de yüksek miktarlarda sentezinin solucan, sıçan, fare, zebra balığı, sinek gibi pek çok hayvan modelinde doza bağlı olarak nörotoksisiteye neden olduğunu göstermiştir. TDP-43 inklüzyonlarının, toksik etki için gerekli olmadı̆̆1, aksine, RNA bağlayıcı motifin (RRM1) varlığııın, TDP-43'ün aşırı ekspresyonu sonucu oluşan toksisite için gerekli olduğu görülmüştür (21,65-67). 
Drosophila modelindeki son çalışmalar nörotoksisitenin, RNA bağlama kapasitesinden ve/veya TDP-43'ün hücre içindeki yanlış konumundan kaynaklandığına işaret etmektedir. TDP43'den yoksun homozigot fare ve sinekler (knockdown), embriyonal evrede öldükleri için, proteinin işlevini anlama çabaları bu modellerde sonuç vermemiştir. TDP-43 işlevi ile ilgili bugüne kadar elde edilen bilgilerin çoğu hücre kültürü modellerinden kaynaklanmaktadır (68-73).

TDP-43'ün aşırı üretimi, hayvan modellerinde olduğu gibi mayada da toksik etki yapar. Maya modelinde, SCA2 ile ilişkilendirilmiş ataksin-2 proteininin ortologu olan $\mathrm{Pbpl}$ 'in, TDP-43 aşırı üretimine bağlı toksisiteyi düzenlediğinin görülmesi üzerine ALS hastalarında yapılan çalışmalar, ataksin-2'nin ALS oluşumu için bugüne kadar bulunmuş en önemli risk faktörü olduğunu göstermiştir. Ataksin-2 ve TDP-43'ün etkileşim mekanizması henüz netlik kazanmamıştır (74-81).

Memeli kültür hücrelerinde veya primer nöronlarda yapılan çalışmaların çoğunda, aşırı üretilen TDP-43 proteininin natif halde çekirdekte kaldı $\breve{g}_{1}$ gösterilmiştir. Bu durum, TDP-43'ün aşırı üretiminin, hücre işlevini bozmak için sadece agregasyon ya da inklüzyon mekanizmalarına bağ $l_{1}$ olmadığııı gösterir. Son bulgulara göre fazla sentezlenen eksojen TDP-43, endojen TDP-43 mRNA'larının 3'UTR bölgelerine bağlanarak bunları yıkıma uğratır (otoregülasyon döngüsü). TDP-43 bağlanma bölgeleri birçok mRNA'da bulunduğu için TDP-43'ün aşırı üretimi, çok sayıda hedef RNA'nın kırpılmasını ve stabilitesini doğrudan değiştirir. Böylece, memeli hücrelerindeki aşırı TDP-43 üretimi, sitozol ve proteotoksik stres altında oluşan TDP-43 agregatları veya hedef mRNA'ların kırpılmasında ve stabilitesindeki değişimler tarafından tetiklenebilir. Bu olasılıklardan hangisinin daha birincil önemi olduğu ve hastalıkla ilişkileri yoğun araştırma konusudur (82-90).

\section{Sonsöz}

Nöronal dejenerasyon ve reaktif gliyoz yanında yanlış katlanmış proteinlerin agregasyonu birçok nörodejeneratif hastalı̆̆ın ortak noktasıdır. TDP-43-temelli ALS ve FTLD araştırmaları son beş yılda çok hızlı ilerlemeler göstermesine rağmen, TDP-43 proteinopatilerinin patolojisi hala birçok bilinmezler içermektedir. Nörodejeneratif hastalıkların çoğunluğunda, mutasyonlar sonucu ve/veya posttranslasyonel süreçlerde çözünülürlüğü azalan ve agregasyon oluşturan moleküllerin yeni bir toksik işlev kazandı $\breve{g} 1$ düşünülmektedir (GOF: gain of function). $\mathrm{Bu}$ da yaşlanmış hücrenin detoksifikasyon ve agrege olmuş proteini yıkma kapasitesini zorlamaktadır. SMA ve FA gibi nörodejeneratif hastalıklarda ise farklı bir mekanizma etkindir, hastalık yaşamsal önemi olan bir proteinin işlevini kaybetmesi sonucu ortaya çıkmaktadır (LOF: loss of function). Bu mekanizmaların hangisinin TDP-43 (ve FUS) için geçerli olduğu henüz bilinmemektedir. Belki ikisi de geçerlidir ve her iki mekanizma birbiri ile etkileşmektedir. Bu etkileşim esnasında RNA işlenmesinde önemi olan bazı proteinlerin de TDP-43 agregatları tarafından hapsedilerek, RNA metabolizmasında ek hasarlara yol açtıkları düşünülebilir. Ya da RNA metabolizmasındaki TDP-43 kaynaklı bozuklukların, posttranslasyonel modifikasyon, protein sentezi ve y1kımını düzenleyen kilit moleküllerin ekspresyon düzeylerini değiştirerek, TDP-43 agregasyonuna olumsuz katkılarda bulunması da mümkündür.

TDP-43 patogenezini anlamak için, TDP-43 agregasyonunu ve inklüzyon cisimciği oluşumunu düzenleyen önemli mekanizmaları aydınlatmak, olası birlikte çöken proteinleri tanımlamak ve patolojik mutasyonların etki mekanizmalarını çözmek gerekmektedir. Mevcut ve gelecekte planlanan hücre ve hayvan modellerinin kapsamlı analizleri hastalık sürecinde etkin olan hedef RNA'ları ve genelde RNA metabolizmasını anlamak açısından büyük önem taşımaktadır. Hedef genlerin sayısı hızla artmakla birlikte, bugüne kadar, pleiotropik TDP-43'ün RNA metabolizmasındaki kesin rolünün ne olduğuna 1 şı tutacak moleküller bulunmamıştır. TDP-43'ün, hücre-içi kompartmanlar, hücre türleri ve hastalık evresine göre değişiklik gösteren büyük hnRNP kompleksleri çerçevesinde görev yapması da olasıdır. Ancak bu kompleks katmanların çözülmesiyle TDP-43 proteinopatilerinin patojenik etki mekanizmaları anlaşılacaktır.

ALS'yi örnek alacak olursak: Son yillarda birçok araştırmacı ALS'nin tek tip bir hastalık olmadı $\breve{g}_{1 n} 1$, örtüşmeyen bir dizi mekanizmanın neden olduğu hastalıklardan oluşan bir spektrum olduğunu dile getirmektedir. Bu durumda yukarıda bahsedilen proteostaz temelli terapi yaklaşımları her ALS tipi için farklı olacaktır, bu da çok güçtür. Belki de tüm ALS türleri -ailesel ve sporadikRNA-temelli ortak bir etiyolojiye sahiptir. Bu durumda ALS için sadece proteostaza dayalı tedavi yaklaşımları (örneğin ilgili proteinin natif formunu stabilize etmek ve katlanma bozukluğunu tetikleyen kovalent bağları engellemek gibi) geliştirmek yeterli olmayabilir. Buna ilaveten RNA biyolojisi yolaklarını hedef alan farklı tedaviler gerekebilir. Ĕger ALS'nin tüm formları RNA kalite kontrol yolaklarındaki hatalardan kaynaklanıyorsa, proteostazdan ziyade RNAstazis türü daha da yeni kavramların ve mekanizmaların devreye girmesi ve araştırılması kaçınılmazdır (54).

\section{Teşekkür}

Suna ve İnan Kıraç Vakfı'na ve Boğaziçi Üniversitesi Araştırma Fonuna destekleri için, Ece Kartal'a yazıya katkılarından dolayı teşekkür ederiz.

\section{Sözlük}

Amiloid fibril: Çapraz $\beta$ yapısı ve bir takım özgün özellikleri olan protein agregasyonlar1

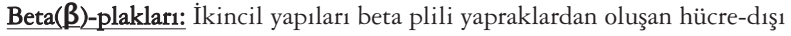
protein agregatları

İnklüzyon cisimcikleri: Hücre-içi protein agregatları

İşlevsel amiloid: Canlı sistemler için yararlı işlevleri olan amiloid yapısı Oligomer: Sınırlı sayıda monomer içeren bir polimer

P-cisimcikleri (Processing bodies): Sitoplasmik RNA depolama veyıkımı molekülleri 
Pleiotropik: tek bir alelin, bir organizmanın fenotipinin daha önceden bağlantılı oldukları bilinmeyen farklı yönlerini değiştirme özelliği.

Polipeptit: Amino asitlerden oluşan kısa protein zincirleri (Genelde 100 amino asitten kısa olduğu durumlarda kullanılır.)

Protein birikimi hastalıkları: Hücre içi ve hücre dışı protein birikimlerinin yol açtı̆̆ $\breve{1}_{1}$ patolojik durumlar

Protein yanlış katlanması: Proteinin natif/doğal yapısından farklı bir yapıya dönüşmesi

Proteinopati: Hatalı katlanan proteinlerin etkisiyle ortaya çıkan

hastalıklara verilen genel isim

Proteom: Bir hücredeki proteinlerin tümü

Proteostaz: Protein ve homeostaz kelimelerinden üretilen proteostaz kavramı, hücre içinde proteinlerin üretim, katlanma, taşınma ve yıkım aşamalarını düzenleyen tüm biyolojik yolakları ifade eder.

Protofibriller: Belirgin beta-plak yapiları olan izole ya da toplu halde görülen toksik olduğu düşünülen protein agregatları

Stres granülleri: Sitoplasmik RNA depolama molekülleri

Şaperon: Proteinlerin üç boyutlu hâle gelmesi işleminde görev alan yardımcı proteinler

Ubikitin Proteozom Sistemi (UPS): Ubikitin olarak adlandirılan

proteinin bağlanması ile başlayan proteozomal yıkım sisteminin genel adı Kisaltmalar

3'UTR: 3' Çevrilmeyen Bölge

AD: Alzheimer Hastalı̆̆ 1

ALS: Amiyotrofik Lateral Skleroz

DN: Distrofik nöritler

DNA: Deoksiribonükleik asit

FTLD: Frontotemporal Lobar Demans

FUS: (Fused in Sarcoma)

GCI: Gliyal sitoplazmik inklüzyonlar

GOF: İşlev kazanma

HD: Huntington Hastalı̆

hnRNP: Heterojen ribonükleoprotein

LOF: İşlev kaybı

mRNA: Mesajcı RNA

$\mathrm{N}$ : Asparajin

NCI: Nöronal sitoplazmik inklüzyonlar

NES: Nükleer eksport sinyali

NII: Nöronal internükleer inklüzyonlar

NLS: Nükleer lokalizasyon sinyali

PD: Parkinson Hastalığ

Q: Glutamin

RNA: Ribonükleik asit

RRM: RNA tanıma motifi

SCA: Spinoserebellar Ataksi

SOD: Süperoksit dismutaz

TDP-43: TAR DNA-bağlanma proteini 43

Ub: Ubikitin

UPS: Ubikitin Proteozom Sistemi

VCP: Valozin içeren protein

\section{Kaynaklar}

1. Chiti F, Dobson CM. Protein misfolding, functional amyloid, and human disease. Annu Rev Biochem 2006;75:333-66.

2. Soto C, Estrada LD. Protein misfolding and neurodegeneration. Arch Neurol 2008;65:184-9.
3. Cohen TJ, Lee VM, Trojanowski JQ. TDP-43 functions and pathogenic mechanisms implicated in TDP-43 proteinopathies. Trends Mol Med 2011;17:659-67.

4. Vendruscolo M, Knowles TPJ, Dobson CM. In: Morimoto R, Selkoe D, Kelly J (eds). Protein Homeostasis. 1 ed. New York: Cold Spring Harbor Laboratory Press, 2011:1-12.

5. Ovadi J, Orosz F. Protein Folding and Misfolding: Neurodegenerative Diseases (Focus on structrural biology 7). EDITION. BASIM YERİ: Springer pres, 2008.

6. Smith HJ, Simons C, Sewell RDE. Protein Misfolding in Neurodegenerative Diseases: Mechanisms and Therapeutic Strategies (Enzyme Inhibitor Series). 1st ed. Florida: CRC Press, 2008.

7. Naeem A, Fazili NA. Defective protein folding and aggregation as the basis of neurodegenerative diseases: the darker aspect of proteins. Cell Biochem Biophys 2011;61:237-50.

8. Pierre S, Vernace V, Wang Z, Figueiredo-Pereira ME. Assembly of Protein Aggregates in Neurodegeneration: Mechanisms Linking the Ubiquitin/Proteasome Pathway and Chaperones. Springer Press 2007;67-79.

9. Tai HC, Schuman EM. Ubiquitin, the proteasome and protein degradation in neuronal function and dysfunction. Nat Rev Neurosci 2008;9:826-38.

10. Calamini B, Silva MC, Madoux F, Hutt DM, Khanna S, Chalfant MA, et al. Small-molecule proteostasis regulators for protein conformational diseases. Nat Chem Biol 2011;8:185-96.

11. Gidalevitz T, Prahlad V, Morimoto RI. The Stress of Protein Misfolding: From Single Cells to Multicellular Organisms. In: Morimoto R, Selkoe D, Kelly J (eds). Protein Homeostasis. 1st ed. New York: Cold Spring Harbor Laboratory Press, 2011:87.

12. Wong ESP, Tan JMM, Lim K. Dynamic Role of Ubiquitination in the Management of Misfolded Proteins Associated with Neurodegenerative Diseases. Springer Pres 2009:77-95.

13. Baloh RH. TDP-43: the relationship between protein aggregation and neurodegeneration in amyotrophic lateral sclerosis and frontotemporal lobar degeneration. FEBS J 2011;278:3539-49.

14. Luheshi LM, Crowther DC, Dobson CM. Protein misfolding and disease: from the test tube to the organism. Curr Opin Chem Biol 2008;12:25-31.

15. Jellinger KA. Recent advances in our understanding of neurodegeneration. J Neural Transm 2009;116:1111-62.

16. Treusch S, Cyr DM, Lindquist S. Amyloid deposits: protection against toxic protein species? Cell Cycle 2009;8:1668-74.

17. Vabulas RM, Raychaudhuri S, Hayer-Hartl M, Hartl FU. Protein Folding in the Cytoplasm and the Heat Shock Response. Morimoto R, Selkoe D, Kelly J. Protein Homeostasis. 1st ed. New York: Cold Spring Harbor Laboratory Press, 2011: 104.

18. Lobsiger CS, Cleveland DW. Glial cells as intrinsic components of non-cellautonomous neurodegenerative disease. Nat Neurosci 2007;10:1355-60.

19. Ilieva H, Polymenidou M, Cleveland DW. Non-cell autonomous toxicity in neurodegenerative disorders: ALS and beyond. J Cell Biol 2009;187:761-72.

20. Buratti E, Baralle FE. The molecular links between TDP- 43 dysfunction and neurodegeneration. Adv Genet 2009;66:1-34.

21. Silva MC, Fox S, Beam M, Thakkar H, Amaral MD, Morimoto RI. A genetic screening strategy identifies novel regulators of the proteostasis network. PLoS Genet 2011;7:e1002438.

22. Forman MS, Trojasnowski JQ, Lee VM. Neurodegenerative diseases: a decade of discoveries paves the way for the therapeutic breakthroughs. Nature 2004;10:1055-63.

23. Yokeş MB, Başak AN. Alzheimer Hastalığının Moleküler Biyolojisi. TJN 2005;11-2:201-22.

24. Taner NE. Alzheimer Hastalığının Genetiği: Son 20 Yılda Öğrenilen Dersler. TJN 2010;16-1:1-11.

25. Yüksel G, Karlıkkaya G, Tireli H. İdiyopatik Parkinson Hastalığında Transkraniyal Manyetik Stimülasyon. TJN 2006;12-2:106-11.

26. Ozansoy M, Başak AN. Parkinson Hastalığının Genetiği ve Nörodejenerasyonun Moleküler Biyolojisi, Parkinson Hast. Hareket Boz Der 2004;7-2:109-20.

27. Ersoy N, Başak AN. Huntington Hastalığı'nın Moleküler Biyolojisi. TJN 2005;11-1:27-44.

28. Şener HÖ, Parman Y, Şengün İ, Koç F, Oflazer P. Amiyotrofik Lateral Sklerozda Kök Hücre Uygulamaları. TJN 2009;15-3:105-08. 
29. Ali AB, Nin DS, Tam J, Khan M. Role of chaperone mediated autophagy (CMA) in the degradation of misfolded N-CoR protein in non-small cell lung cancer (NSCLC) cells. PLoS One 2011;6:e25268.

30. Thomas SE, Dalton L, Malzer E, Marciniak SJ. Unravelling the story of protein misfolding in diabetes mellitus. World J Diabetes 2011;2:114-8.

31. Geser F, Martinez-Lage M, Kwong LK, Lee VM, Trojanowski JQ. Amyotrophic lateral sclerosis, frontotemporal dementia and beyond: the TDP-43 diseases. J Neurol 2009;256:1205-14.

32. Ou SH, Wu F, Harrich D, Garcia-Martinez LF, Gaynor RB. Cloning and characterization of a novel cellular protein, TDP-43, that binds to human immunodeficiency virus type 1 TAR DNA sequence motifs. J Virol 1995;69:3584-96

33. Buratti E, Dork T, Zuccato E, Pagani F, Romano M, Baralle FE. Nuclear factor TDP-43 and SR proteins promote in vitro and in vivo CFTR exon 9 skipping. EMBO J 2001;20:1774-84.

34. He Y, Smith R. Nuclear functions of heterogeneous nuclear ribonucleoproteins A/B. Cell Mol Life Sci 2009;66:1239-56.

35. Kwong LK, Uryu K, Trojanowski JQ, Lee VM. TDP-43 proteinopathies: neurodegenerative protein misfolding diseases without amyloidosis. Neurosignals 2008;16:41-51.

36. Geser F, Robinson JL, Malunda JA, Xie SX, Clark CM, Kwong LK, et al. Pathological $43-\mathrm{kDa}$ transactivation response DNA-binding protein in older adults with and without severe mental illness. Arch Neurol 2010;67:1238-50

37. Weihl CC, Temiz P, Miller SE, Watts G, Smith C, Forman M, et al. TDP-43 accumulation in inclusion body myopathy muscle suggests a common pathogenic mechanism with frontotemporal dementia. J Neurol Neurosurg Psychiatry 2008;79:1186-9.

38. Olive M, Janue A, Moreno D, Gamez J, Torrejon-Escribano B, Ferrer I. TAR DNA-Binding protein 43 accumulation in protein aggregate myopathies. J Neuropathol Exp Neurol 2009;68:262-73.

39. Neumann M. Molecular neuropathology of TDP- 43 proteinopathies. Int J Mol Sci 2009;10:232-46.

40. Neumann M, Sampathu DM, Kwong LK, Truax AC, Micsenyi MC, Chou TT, et al. Ubiquitinated TDP-43 in frontotemporal lobar degeneration and amyotrophic lateral sclerosis. Science 2006;314:130-3.

41. Fecto F, Siddique T. Making connections: pathology and genetics link amyotrophic lateral sclerosis with frontotemporal lobe dementia. J Mol Neurosci 2011;45:663-75.

42. Ritson GP, Custer SK, Freibaum BD, Guinto JB, Geffel D, Moore J, et al. TDP-43 mediates degeneration in a novel Drosophila model of disease caused by mutations in VCP/p97. J Neurosci 2010;30:7729-39.

43. Sreedharan J, Blair IP, Tripathi VB, Hu X, Vance C, Rogelj B, et al. TDP-43 mutations in familial and sporadic amyotrophic lateral sclerosis. Science 2008;319:1668-72.

44. Rutherford NJ, Zhang YJ, Baker M, Gass JM, Finch NA, Xu YF, et al. Novel mutations in TARDBP (TDP-43) in patients with familial amyotrophic lateral sclerosis. PLoS Genet 2008; 4:e1000193.

45. Daoud H, Valdmanis PN, Kabashi E, Dion P, Dupre N, Camu W, et al. Contribution of TARDBP mutations to sporadic amyotrophic lateral sclerosis. J Med Genet 2009; 46:112-4.

46. Borroni B, Bonvicini C, Alberici A, Buratti E, Agosti C, Archetti S, et al. Mutation within TARDBP leads to frontotemporal dementia without motor neuron disease. Hum Mutat 2009;30:E974-83.

47. Benajiba L, Le Ber I, Camuzat A, Lacoste M, Thomas-Anterion C, Couratier $\mathrm{P}$, et al. TARDBP mutations in motoneuron disease with frontotemporal lobar degeneration. Ann Neurol 2009;65:470-3.

48. Chen-Plotkin AS, Lee VM, Trojanowski JQ. TAR DNA-binding protein 43 in neurodegenerative disease. Nat Rev Neurol 2010;6:211-20.

49. Dion PA, Daoud H, Rouleau GA. Genetics of motor neuron disorders: new insights into pathogenic mechanisms. Nat Rev Genet 2009;10:769-82.

50. Beleza-Meireles A, Al-Chalabi A. Genetic studies of amyotrophic lateral sclerosis: controversies and perspectives. Amyotroph Lateral Scler 2009;10:1-14.

51. Rothstein JD. Current hypotheses for the underlying biology of amyotrophic lateral sclerosis. Ann Neurol 2009;65 Suppl 1:S3-9.
52. Vance C, Rogelj B, Hortobagyi T, De Vos KJ, Nishimura AL, Sreedharan J, et al. Mutations in FUS, an RNA processing protein, cause familial amyotrophic lateral sclerosis type 6. Science 2009;323:1208-11.

53. Kwiatkowski TJ Jr, Bosco DA, Leclerc AL, Tamrazian E, Vanderburg CR, Russ C, et al. Mutations in the FUS/TLS gene on chromosome 16 cause familial amyotrophic lateral sclerosis. Science 2009;323:1205-8.

54. Bosco DA, LaVoie MJ, Petsko GA, and Ringe D. Proteostasis and Movement Disorders: Parkinson's Disease and Amyotrophic Lateral Sclerosis. Morimoto R, Selkoe D, Kelly J. Protein Homeostasis. 1st ed. New York: Cold Spring Harbor Laboratory Press, 2011:234-258.

55. Lagier-Tourenne C, Cleveland DW. Rethinking ALS: the FUS about TDP43. Cell 2009;136:1001-4.

56. Anderson P, Kedersha N. RNA granules: post-transcriptional and epigenetic modulators of gene expression. Nat Rev Mol Cell Biol 2009;10:430-6.

57. Colombrita C, Zennaro E, Fallini C, Weber M, Sommacal A, Buratti E, et al. TDP-43 is recruited to stress granules in conditions of oxidative insult. J Neurochem 2009;111:1051-61.

58. Liu-Yesucevitz L, Bilgutay A, Zhang YJ, Vanderweyde T, Citro A, Mehta T, et al. Tar DNA binding protein-43 (TDP-43) associates with stress granules: analysis of cultured cells and pathological brain tissue. PLoS One 2010;5:e13250

59. Freibaum BD, Chitta RK, High AA, Taylor JP. Global analysis of TDP-43 interacting proteins reveals strong association with RNA splicing and translation machinery. J Proteome Res 2010;9:1104-20.

60. Strong MJ, Volkening K. TDP-43 and FUS/TLS: sending a complex message about messenger RNA in amyotrophic lateral sclerosis? FEBS J 2011;278:3569-77.

61. Thomas MG, Loschi M, Desbats MA, Boccaccio GL. RNA granules: the good, the bad and the ugly. Cell Signal 2011;23:324-34.

62. Dewey CM, Cenik B, Sephton CF, Dries DR, Mayer P, 3rd, Good SK, et al. TDP-43 is directed to stress granules by sorbitol, a novel physiological osmotic and oxidative stressor. Mol Cell Biol 2011;31:1098-108.

63. Kiebler MA, Bassell GJ. Neuronal RNA granules: movers and makers. Neuron 2006;51:685-90.

64. Buchan JR, Parker R. Eukaryotic stress granules: the ins and outs of translation. Mol Cell 2009;36:932-41

65. Swarup V, Phaneuf D, Bareil C, Robertson J, Rouleau GA, Kriz J, et al. Pathological hallmarks of amyotrophic lateral sclerosis/frontotemporal lobar degeneration in transgenic mice produced with TDP-43 genomic fragments. Brain 2011;134:2610-26.

66. Joyce PI, Fratta P, Fisher EM, Acevedo-Arozena A. SOD1 and TDP-43 animal models of amyotrophic lateral sclerosis: recent advances in understanding disease toward the development of clinical treatments. Mamm Genome 2011;22:420-48.

67. Xu YF, Zhang YJ, Lin WL, Cao X, Stetler C, Dickson DW, et al. Expression of mutant TDP-43 induces neuronal dysfunction in transgenic mice. Mol Neurodegener 2011; 6:73.

68. Liachko NF, Guthrie CR, Kraemer BC. Phosphorylation promotes neurotoxicity in a Caenorhabditis elegans model of TDP-43 proteinopathy. J Neurosci 2010;30:16208-19.

69. Ash PE, Zhang YJ, Roberts CM, Saldi T, Hutter H, Buratti E, et al Neurotoxic effects of TDP-43 overexpression in C. elegans. Hum Mol Genet 2010;19:3206-18.

70. Laird AS, Van Hoecke A, De Muynck L, Timmers M, Van den Bosch L, Van Damme $\mathrm{P}$, et al. Progranulin is neurotrophic in vivo and protects against a mutant TDP-43 induced axonopathy. PLoS One 2010;5:e13368.

71. Miguel L, Frebourg T, Campion D, Lecourtois M. Both cytoplasmic and nuclear accumulations of the protein are neurotoxic in Drosophila models of TDP-43 proteinopathies. Neurobiol Dis 2011;41:398-406.

72. Voigt A, Herholz D, Fiesel FC, Kaur K, Muller D, Karsten P, et al. TDP-43mediated neuron loss in vivo requires RNA-binding activity. PLoS One 2010;5:e12247.

73. Li Y, Ray P, Rao EJ, Shi C, Guo W, Chen X, et al. A Drosophila model for TDP-43 proteinopathy. Proc Natl Acad Sci U S A 2010;107:3169-74.

74. Elden AC, Kim HJ, Hart MP, Chen-Plotkin AS, Johnson BS, Fang X, et al. Ataxin-2 intermediate-length polyglutamine expansions are associated with increased risk for ALS. Nature 2010;466:1069-75. 
75. Lee T, Li YR, Ingre C, Weber M, Grehl T, Gredal O, et al. Ataxin-2 intermediate-length polyglutamine expansions in European ALS patients. Hum Mol Genet 2011;20:1697-700

76. Ross OA, Rutherford NJ, Baker M, Soto-Ortolaza A, Carrasquillo MM, DeJesus-Hernandez $\mathrm{M}$, et al. Ataxin-2 repeat-length variation and neurodegeneration. Hum Mol Genet 2011;20:3207-12.

77. Corrado L, Mazzini L, Oggioni GD, Luciano B, Godi M, Brusco A, et al. ATXN-2 CAG repeat expansions are interrupted in ALS patients. Hum Genet 2011;130:575-80.

78. Van Damme P, Veldink JH, van Blitterswijk M, Corveleyn A, van Vught PWJ, Thijs V, et al. Expanded ATXN2 CAG repeat size in ALS identifies genetic overlap between ALS and SCA2. Neurology 2011;76:2066-72.

79. Gispert S, Kurz A, Waibel S, Bauer P, Liepelt I, Geissen C, et al. The modulation of Amyotrophic Lateral Sclerosis risk by Ataxin-2 intermediate polyglutamine expansions is a specific effect. Neurobiol Dis 2012;45:356-61.

80. Daoud H, Belzil V, Martins S, Sabbagh M, Provencher P, Lacomblez L, et al. Association of long ATXN2 CAG repeat sizes with increased risk of amyotrophic lateral sclerosis. Arch Neurol 2011;68:739-42.

81. Chen Y, Huang R, Yang Y, Chen K, Song W, Pen P, et al. Ataxin-2 intermediate-length polyglutamine: a possible risk factor for Chinese patients with amyotrophic lateral sclerosis. Neurobiol Aging 2011;32:1925 e1921-5.

82. Wang HY, Wang IF, Bose J, Shen CK. Structural diversity and functional implications of the eukaryotic TDP gene family. Genomics 2004;83:130-9.
83. Ayala YM, Zago P, D'Ambrogio A, Xu YF, Petrucelli L, Buratti E, et al. Structural determinants of the cellular localization and shuttling of TDP-43. J Cell Sci 2008;121:3778-85.

84. Winton MJ, Igaz LM, Wong MM, Kwong LK, Trojanowski JQ, Lee VM. Disturbance of nuclear and cytoplasmic TAR DNA-binding protein (TDP43) induces disease-like redistribution, sequestration, and aggregate formation. J Biol Chem 2008, 283:13302-9.

85. Zhang YJ, Xu YF, Cook C, Gendron TF, Roettges P, Link CD, et al. Aberrant cleavage of TDP-43 enhances aggregation and cellular toxicity. Proc Natl Acad Sci U S A 2009;106:7607-12.

86. Nonaka T, Kametani F, Arai T, Akiyama H, Hasegawa M. Truncation and pathogenic mutations facilitate the formation of intracellular aggregates of TDP-43. Hum Mol Genet 2009;18:3353-64.

87. Barmada SJ, Skibinski G, Korb E, Rao EJ, Wu JY, Finkbeiner S. Cytoplasmic mislocalization of TDP-43 is toxic to neurons and enhanced by a mutation associated with familial amyotrophic lateral sclerosis. J Neurosci 2010;30:639-49.

88. Ayala YM, De Conti L, Avendano-Vazquez SE, Dhir A, Romano M, D'Ambrogio A, et al. TDP-43 regulates its mRNA levels through a negative feedback loop. EMBO J 2011;30:277-88.

89. Buratti E, Baralle FE. TDP-43: new aspects of autoregulation mechanisms in RNA binding proteins and their connection with human disease. FEBS J 2011;278:3530-8

90. Sephton CF, Cenik C, Kucukural A, Dammer EB, Cenik B, Han Y, et al. Identification of neuronal RNA targets of TDP-43-containing ribonucleoprotein complexes. J Biol Chem 2011;286:1204-15. 